\title{
Impact of external physical effects on water and aqueous solutions: the problem of "memory"
}

\author{
(C) Ksenia A. Nurislamova, ${ }^{1}$ Vyacheslav F. Markov, ${ }^{1,2} *^{+}$ \\ Alena S. Franz, ${ }^{1}$ and Larisa N. Maskaeva ${ }^{1,2}$ \\ ${ }^{1}$ Ural Federal University Named after the First President of Russia B.N. Yeltsin. Mira St., 19. Ekaterinburg, \\ 620002. Sverdlovsk Region.Russia.Phone:+7 (343) 375-93-18.E-mail: mln@ural.ru \\ ${ }^{2}$ Ural institute State Fire Service of EMERCOM of Russia. Mira St., 22. Ekaterinburg, 620002. Russia. \\ Phone: +7 (343) 360-81-68.E-mail:v.f.markov@urfu.ru
}

*Supervising author; ${ }^{+}$Corresponding author Keywords: "memory" of aqueous solutions, physicochemical properties of water, physical effects, water clusters, hydrogen bond, influence of prehistory.

\begin{abstract}
A brief analysis of scientific publications on the changes in the physicochemical properties of water and aqueous solutions under the influence of temperature, magnetic and electric fields, laser and microwave radiation, ultrasound, and mechanical mixing was performed. A number of researchers have shown the influence of such effects on changes in $\mathrm{pH}$ and redox potential, electrical conductivity, surface tension and viscosity of an aqueous solution. The question of influence of external physical effects on water and aqueous solutions remains controversial. Some scientists suggest that water has a cluster structure, which is influenced by physical effects. An important aspect of the problem is the impact on the subsequent behavior and the final result of a chemical process involving previously treated aqueous solutions. Using water solutions of lead and thiourea as an example, the effect of their temperature prehistory in the range of 275-369 K on the kinetics of precipitation of the solid phase of lead sulfide and their microstructure is demonstrated. A threefold change in the composition of supersaturated $\mathrm{Cd}_{\mathrm{x}} \mathrm{Pb}_{1-\mathrm{x}} \mathrm{S}$ solid solutions precipitated from solutions containing a lead salt with different temperature prehistory was established. It is shown that the "memory" on the preliminary temperature effect is maintained for at least a day. The influence of electromagnetic treatment of water and aqueous solutions on the content of dissolved oxygen, $\mathrm{pH}$ and electrical conductivity is analyzed. Some scientists explain these results by the influence of the field on the structure of hydrogen bonds, others by a change in the cluster structure of water, as well as by the presence of ferromagnetic particles in water. The review presents the current state of the problem of the "memory" effect and the related influence of the prehistory of the impact of physical factors. The review suggested that the "memory" of an aqueous solution is the preservation for a certain time of the changes in its structure and properties that have arisen as a result of the effect. The basic ideas about the mechanisms of influence of the prehistory of physical effects on aqueous solutions are given.
\end{abstract}

\section{References}

[1] E.G. Bondarenko, I.N. Minina. The state of water in various physical and chemical conditions. Leningrad: Leningrad University.1986. P.182-188. (russian)

[2] S.V. Zenin, B.V. Tyaglov. Hydrophobic model of the structure of associates of water molecules. J. of Physical Chemistry. 1994. Vol. 68. No.4. P.636-641. (russian)

[3] G.A. Krestov, V.A. Kobenin. Thermodynamics of structural changes in water associated with the hydration of polyatomic ions at various temperatures. Physical chemistry of solutions. Moscow: Science. 1972. P. 307. (russian)

[4] G.A. Krestov, V.A. Kobenin. Thermodynamics of structural changes in water during the dissolution of salts at various temperatures. Physical chemistry of solutions. Moscow: Science. 1972. P.307. (russian)

[5] G.A.Krestov, V.K.Abrosimov. Thermodynamics of the dissolution of ammonium nitrate and sodium perrenate in water at various temperatures. Physical chemistry of solutions. Moscow: Science. 1972. P.307. (russian)

[6] G.A. Krestov, V.A. Kobenin. Thermodynamic characteristics of the process of dissolution of thallium and lanthanum nitrates in water at various temperatures. Physical chemistry of solutions. Moscow: Science. 1972. P.307. (russian) 
[7] G.A. Krestov, V.K. Abrosimov. Thermodynamics of the dissolution of gadolinium chloride in water at various temperatures. Physical chemistry of solutions. Moscow: Science. 1972. P.307. (russian)

[8] F.A. Letnikov, T.V. Kashcheeva. On the effect of preheating on the properties of water and aqueous solutions. Surface forces in thin films and disperse systems: collection of reports of the IV conference on surface forces. Moscow: Science. 1972. P.277-281. (russian)

[9] R.D. Oparin, M.V. Fedotova, V.N. Trostin. Investigation of the effect of temperature on the structure of concentrated aqueous solutions of sodium chloride by the method of integral equations. J. of General Chemistry. 2000. Vol.70. No.11. P.1779-1784. (russian)

[10] R.D. Oparin, M.V. Fedotova, A.A. Gribkov, V.N. Trostin. Features of the structure formation of water and concentrated aqueous solutions of lithium halides at low temperatures according to the method of integral equations. Russian Chemical Bulletin. 2003. Vol.52. No.7. P.1402-1410. (russian)

[11] A.V. Donets, V.I. Chizhik. Temperature dependence of the coordination numbers of some monatomic ions in aqueous solutions of electrolytes. J. of Physical Chemistry. 2005. Vol.79. No.6. P.1032-1036. (russian)

[12] A.A. Lapin, and Yu.V. Chugunov. Effect of temperature on the antioxidant activity of water. Butlerov Communications. 2012. Vol.30. No.6. P.113-119. ROI: jbc-02/12-30-6-113

[13] S.V. Shilova, A.N. Bezrukov, A.Ya. Tret'yakova, and W.P. Barabanov. The influence of temperature on self-organization of cationic polyelectrolyte and anionic surfactant in aqueous-alcohol solutions. Butlerov Communications. 2010. Vol.23. No.15. P.61-65. ROI: jbc-02/10-23-15-61

[14] V.V. Goncharuk, E.A. Orekhova, V.V. Malyarenko. Influence of temperature on water clusters. J. of Water Chemistry and Technology. 2008. Vol.30. No.2. P.80-84.

[15] V.F. Markov, L.N. Maskaeva. Water solutions: behavior anomalies. Ekaterinburg: Publisherof the Ural University. 2017. 296p. (russian)

[16] V.F. Markov, L.N. Maskaeva, T.A. Petukhova. The effect of preliminary heat treatment of the components of the reaction mixture on the kinetics of deposition of lead sulfide films. Bulletinof Ural State Technical University. Chemical series. 2004. P.154-156. (russian)

[17] V.F. Markov, L.N. Maskaeva, T.A. Petukhova, V.I. Voronin. Temperature "memory" of an aqueous solution of lead salt: deposition kinetics, structure and properties of PbS films. Surface. X-ray, synchrotron and neural studies. 2007. No.2. P.110-112. (russian)

[18] V.F. Markov, L.N. Maskaeva, and T.A. Alekseeva. Hydrochemical synthesis of metal chalcogenide films. Part 25. Hydrochemical deposition features of metal sulfide and selenide films. Butlerov Communications. 2015. Vol.41. No.1. P.8-21. DOI: 10.37952/ROI-jbc-01/15-41-1-8

[19] D.V. Denisov, S.Yu. Kulikovsky, D.I. Popov. On the possibility of generating a superconducting state of water. Book of reports int. scientific congress 2004 "Fundamental problems of science and technology." 2004. P.106-117. (russian)

[20] V. Ochkov. Water and magnet. Water purification. Water treatment. Water supply journal. 2011. No.10. P.36-48. (russian)

[21] V.I. Klassen. Magnetization of water systems. Moscow: Chemistry. 1978. 296p. (russian)

[22] K. Higashitani, A. Kage, S. Katamura, K. Imai, S. Hatade. Effects of magnetic field on formation of CaCO3 particles. J. Colloid Interface Sci. 1993. No.156. P.90-95.

[23] H.E. Lungader Madsen. Influence of magnetic field on the precipitation of some inorganic salts. $J$. Cryst. Growth. 1995. No.152. P.94-100.

[24] A.V. Isakov. Active protection of equipment from scaling. Engineering practice. 2014. No.2. P.10-11. (russian)

[25] I.E. Stas, O.P. Mikhailova, A.P. Bessonova. The effect of a high-frequency electromagnetic field on the physicochemical properties of distilled water. J. of Chemistry TomskStateUniversity. 2006. No 62. P.4351. (russian)

[26] V.Yu. Chirkova, I.E. Stas. The increase in surface tension and heat of evaporation of water as a result of exposure to a high-frequency electromagnetic field. Izvestiya of Altai State University. 2014. No.3(2). P.187-191. (russian)

[27] V.Yu. Chirkova, N.A. Filimonova. Assessment of the effect of a high-frequency electromagnetic field on the surface tension of water. Chemistry and chemical technology in the 21st century: materials XVI International Scientific and Practical Conference of Students and Young Scientists, dedicated to the 115th anniversary of the birth of Professor L.P. Kuleva (Tomsk, May 25-29, 2015).2015. Vol.1. P.256258. (russian)

[28] V.Yu. Chirkova, I.E. Stas. Assessment of changes in the physicochemical properties of deionized water as a result of electromagnetic effects and various methods. Izvestiya of Altai State University. 2014. No.3. P.243-247. (russian) 
IMPACT OF EXTERNAL PHYSICAL EFFECTS ON WATER AND AQUEOUS SOLUTIONS: THE PROBLEM...

[29] V.A. Khan, V.A. Vlasov. Investigation of the influence of electromagnetic fields on the structure and properties of water. Scientific J. of KubSAU. 2012. No.81. P.115-127. (russian)

[30] Yu.S. Sarkisov, N.P. Gorlenko, V.N. Safronov, S.A. Kugaevskaya. The effect of a magnetic field on dispersed properties. News of higher educational institutions. Construction. 2015. No.7. P.111-118. (russian)

[31] G.N. Sidorenko, B.I. Laptev, N.P. Gorlenko, L.V. Antoshkin. Changing the properties of water and water-containing systems when using low-energy influences. J. PNRPU Bulletin. Chemical Technology and Biotechnology. 2018. No.2. P. 99-118. (russian)

[32] G.N. Sidorenko, B.I. Laptev, N.P. Gorlenko, Yu.S. Sarkisov, L.V. Antoshkin. Assessment of changes in the structural and energy state of water during cooling, heating and the action of a magnetic field using thermometry and electrophysical research methods. J. of Chemistry Tomsk State University. 2017. No.7. P.80-93. (russian)

[33] D.A. Afanasyev, Yu.S. Sarkisov, S.A. Kugaevskaya, V.N. Safronov, N.P. Gorlenko, Yu.A. Abzaev, M.A. Kovaleva, M.Yu. Shevchenko, T.A. Ermilova. Spectral study of water treated with a constant magnetic field. Advanced Materialsin Technology and Construction (AMTC-2015). 2015. P.510-513. (russian)

[34] V.I. Bukatyi, P.I. Nesteryuk. Development of a measuring and computing complex and a method of small scattering angles for monitoring optical inhomogeneities (clusters) in bidistilled water after a magnetic field. Electronic Physics and Technology J. 2012. No.7. P.6-11. (russian)

[35] M.V. Zhidko, B.P. Shipunov The influence of a high-frequency field on the solubility of oxygen in water and its physicochemical properties. Collected papers of I-st International Russian-Kazakhstan Conference on Chemistry and Chemical Technology. Tomsk. 2011. P.77-79. (russian)

[36] J.L. Toledo Evelyn, T.C. Ramalho, M. Magriotis Zuy. Influence of magnetic field on physical-chemical properties of the liquid water: Insights from experimental and theoretical models. J. of Molecular Structure. 2008. No.888. P.409-415.

[37] Y. Wang, B. Zhang, Zh. Gong, K. Gao, Yu. Ou, J. Zhang. The effect of a static magnetic field on the hydrogen bonding in water using frictional experiments. Journal of Molecular Structure. 2013. P.102-104.

[38] M.C. Amiri, Ali A. Dadkhah. On reduction in the surface tension of water due to magnetic. Colloids and Surfaces A: Physicochem. 2006. P.252-255.

[39] Chang K.TWeng, Cheng-I. The effect of an external magnetic field on the structure of liquid water using molecular dynamics simulation. J. of Applied Phys. 2006. P.1-5.

[40] X. Han, Y. Peng, Zh. Ma. Effect of magnetic field on optical features of water and $\mathrm{KCl}$ solutions. Optik. 2016. P.6371-6376.

[41] Y. Wang, H. Wei, Zh. Li. Effect of magnetic field on the physical properties of water. Results in Physics. 2018. P.262-267.

[42] H.B. Amor, A. Elaoud, N.B. Salah, Kh. Elmoueddeb. Effect of magnetic treatment on surface tension and water evaporation. Int. J. of Advance Industrial Engineering. 2017. Vol.5. Iss.3. P.120-124.

[43] R. Cai, H. Yang, J. He, W. Zhu. The effects of magnetic fields on water molecular hydrogen bonds. $J$. of Molecular Structure. 2009. Vol.938. P.15-19.

[44] L. Holysz, A. Szczes, E. Chibowski. Effects of a static magnetic field on water and electrolyte solutions. Colloid and Interface Science. 2007. No.316. P.996-1002.

[45] L. Holysz, A. Szczes, E. Chibowski. Influence of Magnetic Field on Evaporation Rate and Surface Tension of Water. Colloids Interfaces. 2018. No.2(4). P.1-13.

[46] L. Holysz, A. Szczes, E. Chibowski, P. Rafalski. Effects of static magnetic field on water at kinetic condition. Chemical Engineering and Processing. 2011. Vol.5. P.124-127.

[47] J. Nakagawa, N. Hirota, K. Kitazawa, M. Shoda. Magnetic field enhancement of water vaporization. $J$. of Applied Phys. 1999. Vol.86. P.2923-2925.

[48] Y-Z. Guo, D-C. Yin, H-L. Cao, J-Y. Shi, C-Y. Zhang, Y-M. Liu, H-H. Huang, Y. Liu. Evaporation rate of water as a function of a magnetic field and field gradient. Int. J. of Molecular Sciences. 2012. Vol.13. P.16916-16928.

[49] F.L. Rashid, N.M. Hassan, A.M. Jafar, A. Hashim. Increasing water evaporation rate by magnetic field. Int. Science and Investigation J. 2013. Vol.2. P.61-68.

[50] A. Seyfi, R. Afzalzadeha, A. Hajnorouzi. Increase in water evaporation rate with increase in static magnetic field perpendicular to water-air interface. Chemical Engineering and Processing. 2017. Vol.120. P.195-200.

[51] I. Otsuka, S. Ozeki. Does magnetic treatment of water changes its properties. Journal of Physical Chemistry B. 2006. Vol.110. Iss.4. P.1509-1512. 
[52] I.M. Ageev, G.G. Shishkin. Correlation of solar activity with the electrical conductivity of water. Biophysics. 2001. Vol.46. No.5. P.829-832. (russian)

[53] V.I. Bukatyi, P.I. Nesteryuk. Measurement of physico-chemical characteristics of water under various physical influences, taking into account transient processes. Polzunovskyvestnik. 2010. No.2. P.59-64. (russian)

[54] K.S. Musienko, T.M. Ignatova, V.V. Glazkova. Studying the influence of physical fields on the physicochemical properties of water. Biomedical engineering and electronics. 2014. No.2. P.1-7. (russian)

[55] J.L. Toledo Evelyn, R. Custodio, T.C. Ramalho, M.E. Garcia Porto, Z.M. Magriotis. Electrical field effects on dipole moment, structure and energetic of $\left(\mathrm{H}_{2} \mathrm{O}\right)_{\mathrm{n}}(2 \leq \mathrm{n} \leq 15)$ cluster. $J$. of Molecular Structure: Theochem. 2009. P.170-177.

[56] P. Vallee, J. Lafait, L. Legrand, P. Mentre, M.-O. Monod, Y. Thomas. Effects of pulsed low-frequency electromagnetic fields on water characterized by light scattering techniques: role of bubbles. Langmuir. 2005. No.21. P.2293-2299.

[57] A.A. Britova, I.V. Adamko, V. L. Bachurina. Water activation by laser radiation, magnetic field and their combination. Vestnik Nov SU. 1998. No.7. P.1-3. (russian)

[58] A.G. Lipson, V.A. Kuznetsov. The formation of long-lived associated structures of liquid water in external force fields. J. of Technical Physics. 1996. Vol.66. No.6. P.26-36. (russian)

[59] V.F. Kovalenko, V.V. Glazkova. The influence of acoustic waves on the structural properties of water. Biomedical engineering and electronics. 2013. No.1. P.1-13. (russian)

[60] C.V. Gudkov, O.E. Karp, S.A. Garmash, V.E. Ivanov, A.V. Chernikov, A.A. Manokhin, M.E. Astashev, L.C. Yaguzhinsky, V .I. Bruskov. The formation of reactive oxygen species in water under the influence of visible and infrared radiation in the absorption bands of molecular oxygen. Biophysics. 2012. Vol.57. No.1. P.5-13. (russian)

[61] S.V. Lanovetsky, V.Z. Poylov, O.K. Kosvintsev. The effect of temperature, mixing intensity and soluble impurities on the crystallization of magnesium nitrate from a supersaturated aqueous solution. Russian J. of Chemistry and Chemical technology. 2010. Vol.53. No.11. P.48-51. (russian)

[62] S.V. Lanovetsky, V.Z. Poylov, A.M. Sizyakina, A.V. Stepanov. Effect of cooling rate and mixing intensity on the process of mass crystallization of manganese acetate tetrahydrate. Russian J. of Chemistry and Chemical technology. 2010. Vol.53. No.11. P.44-47. (russian)

[63] N.Kh. Ibraev, D.A. Afanasyev. The effect of a magnetic field on triplet-triplet annihilation in systems with limited geometry. Butlerov Communications. 2011. Vol.25. No.8. P.140. ROI: jbc-01/11-25-8-140

[64] Yu.I. Sucharev, I.Y. Apalikova, I.A. Shafrunov, K. Nosov, and B.A. Markov. Optical properties of gel oxyhydrates and gel oxyhydrate "noise". Butlerov Communications. 2010. Vol.20. No.4. P.10-25. ROI: jbc-02/10-20-4-10

[65] N.E. Lebedeva, Yu.V. Kiseleva, S.Yu. Sergeeva, S.A. Ryzhkin, I.S. Ryzhkina, and A.I. Konovalov. Effect of highly diluted aqueous solutions and weak physical fields on the behavior of aquatic organisms. Butlerov Communications. 2015. Vol.42. No.5. P.8-18. DOI: 10.37952/ROI-jbc-01/15-42-5-8

[66] O.V. Mosin, I. Ignatov. Theoretical foundations of magnetic treatment of water. Access mode: http://sernam.ru/htm/sc_work/im_15.pdf.

[67] V.I. Lesin, Yu.A. Koksharov, G.B. Khomutov. Viscosity of liquid suspensions with fractal aggregates: magnetic nanoparticles in petroleum colloidal structures. Colloids and Surfaces A: Physicochemical and Engineering Aspects. 2011. Vol.392. P.88-94. 